University of Nebraska - Lincoln

DigitalCommons@University of Nebraska - Lincoln

$5-2007$

\title{
Evolutionary Theory and Political Leadership:Why Certain People Do Not Trust Decision Makers
}

\author{
Kevin Smith \\ University of Nebraska - Lincoln, ksmith1@unl.edu \\ Christopher W. Larimer \\ University of Northern lowa \\ Levente Littvay \\ Central European University \\ John R. Hibbing \\ University of Nebraska-Lincoln, jhibbing1@unl.edu
}

Follow this and additional works at: https://digitalcommons.unl.edu/poliscifacpub

Part of the Political Science Commons

Smith, Kevin; Larimer, Christopher W.; Littvay, Levente; and Hibbing, John R., "Evolutionary Theory and Political Leadership:Why Certain People Do Not Trust Decision Makers" (2007). Faculty Publications: Political Science. 109.

https://digitalcommons.unl.edu/poliscifacpub/109

This Article is brought to you for free and open access by the Political Science, Department of at DigitalCommons@University of Nebraska - Lincoln. It has been accepted for inclusion in Faculty Publications: Political Science by an authorized administrator of DigitalCommons@University of Nebraska - Lincoln. 


\title{
Evolutionary Theory and Political Leadership: Why Certain People Do Not Trust Decision Makers
}

\author{
Kevin B. Smith University of Nebraska \\ Christopher W. Larimer University of Northern lowa \\ Levente Littvay Central European University \\ John R. Hibbing University of Nebraska
}

\begin{abstract}
Central to social systems are the attitudes of the rank and file toward those who make political decisions (leaders), and attitudes toward leaders are known to be characterized by two fundamental features. First, the modal attitude is acceptance of the necessity of leaders coupled with acute aversion to leaders who are believed to be motivated by ambition and avarice; second, people are highly variable with some being markedly more sensitive than others to the traits of leaders. But the theoretical basis for these empirical facts has yet to be fully elucidated. In this article, we offer such a theory by drawing on biological evolution and then, using a series of laboratory experiments, provide an empirical test of it. Results are fully consistent with evolutionary theory in showing that people are indeed generally sensitive to leadership traits threatening to the larger group even as certain, expected individuals are a good deal more sensitive than others.
\end{abstract}

$\mathrm{O}$ ne of the enduring features of modern representative democracy is people's dissatisfaction with political decision makers (also called leaders). Certainly, during brief periods of time (subsequent to $9 / 11$ in the U.S. case, for example) approval of leaders will exceed disapproval, but this is not the norm (Anderson and Guillory 1997; Craig 1993; Ely 1980; Hetherington 2005; Lipset and Schneider 1987; Nye, Zelikow, and King 1997; Orren 1997; Pharr and Putnam 2000). Dissatisfaction rarely progresses to the point that people want to eliminate decision makers in favor of making political decisions themselves, but it does lead to concern for legitimacy, compliance, and acceptance-central components of politics in anything other than a police state (Citrin 1974; Easton 1965; Hibbing and Theiss-Morse 2002). Though dissatisfaction with political leaders is the norm for polities, cross-sectional variance within populations is substantial and, it turns out, somewhat difficult to explain with standard independent vari- ables. Some people are consistently negative toward decision makers while others may or may not be negative depending upon the circumstances. ${ }^{1}$ In this paper, we offer a theory that accounts for people's generally wary attitude toward political leaders but also their varying levels of sensitivity to environmental circumstances in formulating their attitudes. Then, using a series of original laboratory experiments, we provide an initial test of this theory.

\section{The Evolutionary Value of (Some People) Constraining Group Leaders}

What might explain people's desire to be led but at the same time their tendency to be dissatisfied with those who are leaders? Evolutionary biology provides one possible answer. ${ }^{2}$

Given the competitive and uncertain environment in which groups typically exist, leadership is essential.

${ }^{1} \mathrm{~A}$ third group — those who are always favorable toward government—exists but is sufficiently rare that we will not discuss it here.

${ }^{2}$ Evolutionary biology is increasingly serving as a wellspring of hypotheses in the social sciences, especially economics (Bowles 2004) and psychology (McAndrew 2002), but also in political science (Carmen 2004; Hibbing and Alford 2004; Marcus 2002; Marcus, Neuman, and MacKuen 2000; Masters 1982; McDermott 2004; Monroe 2001; Orbell and Dawes 1991; Orbell et al. 2004; Ostrom 1998; Scharlemannk

The Journal of Politics, Vol. 69, No. 2, May 2007, pp. 285-299 
Many situations, including response to natural disasters, mediating intragroup disputes, securing provisions, and protecting against predators, demand speedy, unequivocal decisions. Groups without leaders will ultimately lose out to groups with leaders. At the same time, bad leaders can be just as pathological to a group as no leaders at all. When a limited number of individuals possesses special authority to make decisions for others, those individuals are also in a position to direct resources to themselves at the expense of other group members, resulting in a dysfunctional group. To avoid this, members of a successful group need to stand ready not only to elevate and obey leaders but also to keep an unblinking eye on those leaders and to be prepared to cut them down to size if they act in a self-serving fashion or seem to believe they deserve special treatment.

Just as social psychologists have demonstrated that people are inclined to elevate and to obey authority figures (see Milgram 1974; Sherif 1937), anthropologists have revealed the universality of what they frequently call "anti-big-man behavior" (see Boehm 1999; Diamond 1997). In every social unit observed, from small hunter-gatherer bands to modern mass societies, "big man behavior" is met with disrespect, derision, and sometimes dismissal. Note that these negative reactions are engendered not by leadership itself but by inappropriate actions on the part of leaders. Leaders who are magnanimous and who do not act as though they are something special are valued; leaders who are self-serving and exude even a whiff of self-importance are quickly upbraided.

It is relatively easy to see the evolutionary advantages that would accrue to a group with leaders but leaders who are held in check. The next question becomes whether a group is better off if everyone in it

et al. 2001; Sell et al. 2004; Somit and Peterson 1997; Sullivan and Masters 1988; Wilson, Eckel, and Johnson 2002). A key attraction is that it provides a theory of human preferences, something analytical constructs such as rational choice and behavioralism make no claims to do since rational choice takes preferences as givens and behavioralism is content to focus on proximate environmental influences on behavior. Evolutionary explanations openly address ultimate causes whereas other theories employed in the social sciences today offer only proximate explanations without considering distal causes. For example, social acceptance theory is based on the notion that people want to be accepted by a social group but it does not specify why people are the way they are. The disadvantage of evolutionary explanations is that it is quite difficult to test their veracity since recreating the environment of evolutionary adaptation is impossible (though computer simulations are helpful). The issue becomes whether it is preferable to entertain theories of ultimate causes even if those theories cannot be completely tested or to continue to ignore distal causes, thereby engaging in "incoherent environmentalism" (Tooby and Cosmides 1992). We opt for the former even as we recognize its limitations. is equally vigilant against arrogant, selfish leaders or if it is preferable for only some members to stand guard, and here a strong case can be made for the latter. Monitoring leaders is a time-consuming task, one that could be expected to detract from the ability of the group to perform other necessary tasks; thus it may be best for a subset of the population to be sensitive to inappropriate leader behavior while others in the group go about their business unburdened by such concerns and safe in the knowledge that others will sound the alarm should it be needed. As such, monitoring leaders could be another of the many instances in which different types of individuals are valuable within a group. Division of the group into types in order to accomplish diverse tasks is observable in social units as basic as beehives-and if bees are sophisticated enough to diversify, it seems likely humans are too.

We recognize that most social scientists are not accustomed to thinking about people as belonging to recognizable types. Much more common, and perhaps comforting, is the notion that people are born with behavioral blank slates that are then shaped only by environmental, not biological forces. Whether we like it or not, recent research suggests behavioral types are both evolutionarily useful and in evidence empirically. Of course, "types" in this context are not completely rigid, but they do embody observable predispositions and they do make good evolutionary sense.

A beautiful illustration of the evolutionary advantages of having varying types of individuals within a social unit (or at least domain-specific molecules in the brain) is provided by Smirnov et al. (2006). Using computer simulations and recognizing that altruism directed outside of the group (heroism) is quite different than altruism directed at other ingroup members (communitarianism), this research team demonstrates the advantages accruing to the group when heroes and communitarians are not the same individuals. The simulations show that groups with separate and set individuals serving as heroes (or as communitarians) out-survive groups in which individuals serve the role of both heroes and communitarians, in other words are general purpose altruists. Similarly, Kurzban and Houser (2005) employ computer simulations to show that groups with a mix of cooperators, free-riders, and reciprocal (or conditional) cooperators are evolutionarily stable. This finding is in turn consistent with more extensive simulation work by Hammond indicating that groups with mixtures of cooperator types, defector types, and conditional cooperator types are at a competitive advantage (Hammond 2000; see also Rauch 2002). The 
notion that evolution eventually drives out variance is simply incorrect except perhaps in the most artificially controlled laboratory setting.

The advantages of diversity are likely the reason that empirical observations reveal so much of it in areas such as physiology and personality. Distinct blood types and immunological strengths increase the odds that certain group members will survive a deadly pathogen even if all are exposed to it. And distinct personality types, which are known to be relatively constant and correlated with specific genetic alleles (see Bouchard and McGue 2003; Carmen 2006; Gosling and John 1999), allow people to respond differently to similar environmental stimuli. For example, a gene relevant to a certain class of dopamine receptors (DRD4) is known to be associated (in males) with "risky 'show-off' behaviors" (Harpending and Cochran 2002, 12). Caspi et al. (2003) recently identified alleles of 5-HTT, a serotonin transport gene, that affect the likelihood that an individual will be susceptible to environmental stressors such as child abuse. Individuals with the long allele are more resistant to the long-term consequences of child abuse than are individuals with the short allele.

We suspect the advantages of diversity also explain the large amount of social and political diversity in groups. Experimental research invariably reveals people with consistent but different patterns of play in economic games (Cason et al. 2003; Fehr and Gachter 2002; Komorita and Parks 1995). A mix of types within a group, whether we are referring to heroes and communitarians or to conditional cooperators and defectors, makes the group stronger (for more on group selection, see Sober and Wilson 1998). Note that groups in which all members are simply flexible and therefore capable of either cooperation or defection depending upon environmental circumstances such as the behavior of others (this would be the equivalent of a group in which all members were conditional or reciprocal cooperators) are not similarly advantaged. Perhaps surprisingly, computer simulations of the evolutionary process indicate that types trump uniformity even if it is uniform flexibility. ${ }^{3}$

If durable types exist, they are likely to be partially genetic, and empirical work is perfectly consistent with this expectation. Research in behavioral genetics has long reported clear findings that personal temperaments such as risk taking and harm avoidance, as well as personality traits such as conscientiousness,

${ }^{3}$ It should be noted that group selection arguments such as ours are still controversial in biology and that advantages at the group level still need to affect individual fitness at some point. agreeableness, openness, extraversion, and neuroticism, are about $50 \%$ heritable with the remaining half coming from environmental factors (Bouchard and McGue 2003). ${ }^{4}$ Moving to traits more conspicuously directed at other people, altruism appears to be strongly heritable (see Rushton, Littlefield, and Lumsden 1986) as do opinions on social (Martin et al. 1986) and political (Alford, Funk, and Hibbing 2005) issues. Preliminary evidence even suggests there is a genetic component to participation in the political arena (Fowler, Baker, and Pope 2006). Undoubtedly, many individuals whose genotype encourages, for example, political reticence but adherence to traditional values still end up being liberal activists, but this absence of determinism does not obviate the probabilistic relevance of genotypes. In fact, the existence of types may be part of the reason traditional environmental models of political phenomena explain such a small percentage of the total variance (often little more than 10\%). Empirical work in this area is just beginning to gain momentum, but nothing to this point is inconsistent with the expectations derived from evolutionary theory and simulations holding that different types of conspecifics generally will be in evidence.

\section{Evolution as the Theoretical Basis for People's Concern for Procedural Justice}

Applying the logic of evolution to attitudes toward decision makers provides an explanation for a set of important results that heretofore was theoretically inexplicable. Even though the instinct of many political scientists is to assume that people "care about ends not means; they judge government by results and are ... indifferent about the methods by which the results were obtained" (Popkin 1991, 99), oftreplicated empirical results indicate people often are surprisingly oblivious to ends and equally often care intensely about means and methods. People are rarely aware of specific governmental policies (see delli Carpini and Keeter 1996; Hibbing and Theiss-Morse 2002) and the connection between overall conditions and attitudes toward government appears weak (see, for example, Miller 1974, 952-56). For example, a prospering economy does not seem to lead to either greater approval of government or to heightened per-

${ }^{4}$ For an excellent discussion of the specific genetic alleles and therefore biological substrates responsible for these various types of human beings, see Carmen $(2004,2006)$. 
ceptions of governmental legitimacy (Durr, Gilmour, and Wolbrecht 1997; Lawrence 1997). Such findings lead della Porta to ask "why policy outputs ... play such a minor role in shaping confidence in democratic institutions" $(2000,202)$ and Pharr to conclude that "policy performance ... explains little when it comes to public trust" $(2000,199)$. If not the substance of policies or the general favorability of societal conditions, what leads some to embrace their government and others to disparage it?

One answer to this question has been popular in psychology for some time and is now growing in acceptance among political scientists. Evidence indicates that people are surprisingly attuned not just to outcomes but also to the procedures employed by decision makers; that in direct contradiction to Popkin's assertion people crave "procedural justice." Did the process seem neutral? What were the goals of decision makers? Was the decision based on sufficient information? Did people have the chance to provide input before the decision was made? Were diverse views carefully considered? The procedural justice literature finds attitudes toward decisions and decision makers to be strongly influenced by perceptions of the decision-making process. More specifically, it concludes that, independent of substance, favorable perceptions of the decision-making process on average markedly increase legitimacy, satisfaction, approval, and even compliance (Lind and Tyler 1988; Tyler 1990, 1994, 2001; Tyler, Casper, and Fischer 1989; Tyler, Rasinski, and Spodick 1985; for more on the fitness characteristics of procedural as opposed to substantive justice see Simon 1990; Wilson 1993, 23-24, 55-78).

These empirical results are provocative and reproducible, and harbor important and underappreciated implications for the political arena. They are also theoretically impoverished. Yet to be offered is a deeper account of the reasons people are so concerned with process variables. Much of the procedural justice literature offers no greater theoretical basis for the empirical results than the assertion that people simply desire procedural justice, and saying "that is just the way people are" does not constitute a theory. ${ }^{5}$ As

\footnotetext{
${ }^{5}$ The most relevant theoretical exchange is between Thibaut on the one hand and Lind and Tyler on the other (for a summary, see Lind and Tyler 1988). Thibaut (see Thibaut and Walker 1975) believes people's concern for procedural justice is, after all is said and done, really a concern for outcome. People merely recognize that a good process is more likely than a bad process to lead to a favorable substantive result for them. Lind and Tyler (as well as a series of subsequent findings) demonstrate that even with people's expectations about outcome and the actual outcome controlled, procedural matters are still strongly relevant. While this exchange is
}

empirical demonstrations of the importance of procedural justice multiply in number, the absence of a theoretical explanation becomes ever more glaring.

Fortunately, evolutionary theory offers a theoretical account of people's sensitivity to procedural variables. In fact, it provides an explanation for sensitivity to a broader range of factors than just process. These include the motivations of the decision maker not just in making the decision in question but also in wanting to become the decision maker in the first place (on the importance of intentionality, see Falk, Fehr, and Fischbacher 2003; Hibbing and Alford 2004). We will refer loosely to these factors as "nonoutcome" variables since the relevant unifying thread through them is that they do not in any way reflect the substance of the decision outcome.

The central insights of evolutionary biology for humans involve the advantages of group life. Humans have been reaping the benefits of social living for millions of years, probably since shortly after our last common ancestor with orangutans, our closest nonsocial relative (Lee and Devore 1968, 3). Not only are all human units social, the lives of our nearest relatives-chimpanzees, bonobos, and gorillas-are also entirely organized around groups (see de Waal 1996). Groups enhance acquisition of provisions, protection against predators (including outgroup conspecific predators), and reproductive/child rearing potential, ${ }^{6}$ so not being a part of a properly functioning group reduces the odds of reproduction and survival (Tooby and Cosmides 1992).

In response to such pressures, humans could be expected to have evolved a remarkable set of social capacities. ${ }^{7}$ For example, humans can identify subtle moods of others from photographs of their eyes, predict the game-playing behavior of others after visiting with them for just a few minutes, and detect cheaters on the basis of minimal information; even human memory works better when social as opposed to nonsocial factors are at play (Baron-Cohen 2003; Chiappe, Brown, and Rodriquez 2002; Cosmides 1989; Cosmides and Tooby 1992; Frank 1988; Frank, Gilovich, and Regan 1993). In short, group life

clarifying, it leaves us back where we started, knowing that people care about procedural matters independent of outcome, but not knowing why.

${ }^{6}$ In our usage, groups are quite loose and informal, as opposed to the more structured, organized groups frequently described in political science works.

${ }^{7}$ Being social is not automatically "good" as it can entail mindless conformity, unthinking obedience to authority figures, undue competitiveness, taking pleasure in the misfortune of others, and violent hostility toward outgroup members. 
requires a sort of "Machiavellian intelligence" and humans seem to possess it (see Byrne and Whiten 1988; Orbell et al. 2004). While cheater detection, altruistic punishment, and other cooperative tendencies are important and oft-studied elements of humans' evolutionarily derived social repertoire, considerably less attention has been given to the likely implications of more purely political variables such as attitudes toward those who hold special authority in the group-in other words, attitudes toward leaders or decision makers.

Since humans have survived thanks to groups, it makes sense that they have evolved deep concerns for the viability of their group as well as for their own individual status within the group. If a leader's decision on an isolated resource allocation matter is unfavorable to a given individual, the result is unlikely to be dire, but if the nonoutcome factors involved in that decision suggest the individual's status in the group is diminished or if they suggest the group itself is in danger (due to leaders whose motivations are not first and foremost the welfare of the group) the situation becomes much more serious. In this sense, extreme sensitivity to nonoutcome factors that are suspected to be revealing of deeper issues such as the value of an individual or the motivation of a decision maker is perfectly sensible from an evolutionary point of view. An unfavorable decision rendered by chance should be much less troubling to an individual than an identically unfavorable decision rendered on the basis of leader discretion. One means the individual was merely unlucky; the other means the individual is not highly valued by a powerful group member or cluster of members. Similarly, a decision made by an altruistic leader should be much less troubling than if that identical decision comes from a self-serving leader since the latter means the leader's top priority is not the welfare of the group-and this is a problem. In sum, the value people accord procedural justice should be viewed as part of a larger phenomenon of attaching importance to any factor indicative of group health or individual status within the group. These telling factors could be the outcome itself but, for the reasons described above, are more likely to be nonoutcome factors.

Casual observation of politics supports the importance of non-outcome factors. People accept and revere leaders who are believed to be sacrificing for the

\footnotetext{
${ }^{8}$ The argument is that followers must get more than compensating returns out of having leaders and "follower" sensitivity to the traits and motives of the leader may help to achieve this.
}

welfare of the group, who clearly desire no personal benefits from their leadership, or, better yet, did not desire leadership in the first place but are recognized as leaders solely because of their accomplishments. Strong, modest, reticent leaders are looked up to because of their actions and because such leaders lack political ambition. Leaders who can convince the public that they do not crave powerful positions-say, Cincinnatus, Dwight Eisenhower, or Churchill at one point of his career-are generally beloved.

The ability to identify those who desire special dispensations and the willingness to visit immediate social sanctions upon such individuals are longstanding human characteristics that have not atrophied with the advent of modern mass societies and may even be why decision makers are so rarely liked. Group leaders today (with the interesting and revealing exception of inherited monarchies) are typically designated after they have openly declared their desire to be a leader and it may be that this is a main reason they regularly encounter public suspicion. Politicians are, after all, individuals who want to be given special privileges and who boast constantly that they have something unique to offer society. In order for people to approve of an individual displaying this behavior, they would have to resist a long-standing inclination to disapprove of those who believe themselves to be better than others. ${ }^{9}$

Politics in systems that place a premium on individual candidacies (such as the United States) becomes an odd game as a result. Stances on crucial issues of the day, though certainly part of the picture, are frequently less influential than the candidates' stories about why they are seeking office and how selfless they are. They lambaste opponents for being willing to do anything to get elected (flip-flopping, adopting positions popular in public opinion polls, etc.) because successfully impugning the motives of a political opponent often translates into victory. Intense desire for power usually is a disqualification for public office unless a convincing case can be made that power is being sought only to foster the betterment of others. But if our expectation on "types" is correct, this sensitivity to leader traits (such as a desire for power) should be most in evidence for a predictable subset of the population.

\footnotetext{
${ }^{9}$ This suspicion of "big man behavior" even comes out in forms of government as "democratic" as town hall meetings. People who talk a great deal at these meetings or who are perceived to have more influence than others are viewed negatively (Mansbridge 1980).
} 


\section{Experimental Design}

Though it appears to be consistent with casual observation of the political world, for the theory to be convincing more systematic tests are required. Such tests must meet two central requirements. First, since evolutionary theory predicts people are extremely sensitive to the health of their group and their status in the group, it must be possible to vary traits of decision makers likely to be revealing of individual status and group health while holding the outcome itself constant. Second, since evolutionary logic predicts people will come in different types with some more sensitive than others to the traits of decision makers, it must be possible to identify individuals likely to be more attuned than others to these traits. Largely because it would otherwise be too difficult to control outcomes received as well as the traits of decision makers, we employ an experimental design here.

We focus on two decision-maker traits that are likely to be revealing of group health and individual status within the group: whether or not the decision maker is self-interested and whether the decision maker had overt ambitions to become the decision maker. As has been discussed, self-interested leaders have the potential to rent the fabric of group life and personal ambition for power is taken by many people to be an indication of self-interested tendencies. Who would want power so badly other than those hoping to use it for their own ends? To distinguish the various types of people in terms of their sensitivity to decision-maker traits, we asked each experimental subject whether they believe most people can be trusted or whether they believe "you can't be too careful in dealing with people." Even though this widely employed survey item is battle tested, this measure of "type" is far from ideal. In fact, any single survey item is unlikely to capture differences in type across humans. Future research will want to improve identification of types but for this initial test dividing people into more trusting and less trusting types will have to do. Our hypothesis is that more trusting individuals will be more sensitive to the ambition and to the apparent self-interest of leaders.

Even with acknowledgement that a single survey item is a poor measure of type, it may seem strange to hypothesize that sensitivity to leadership traits will be enhanced among trusting individuals. After all, it could be that those who believe most people can be trusted are the ones who do not need to scrutinize leaders since, presumably, they believe leaders can be trusted. This reasoning is incorrect. Research in experimental economics consistently reveals that, compared to selfish and untrusting individuals, those who are generous and trusting are actually more wary and more willing to punish egoists (Fehr and Gachter 2002: 137; Peterson 2006; Price, Cosmides, and Tooby 2002). For evolutionary reasons, people are averse to being played for a sucker, and those people who are trusting and generous are more open to being victimized so it makes sense for them to be more vigilant of decision makers and more concerned with possible violations of the public trust. Those who play the game of life as though everyone is untrustworthy have less reason to be vigilant since their blanket cynicism means they do not have to observe people carefully. They live their lives in a less contingent and more rule-based manner and so should display less differentiation from one type of decision maker to the next. Trusting individuals, on the other hand, need to be attuned to the traits of other people because their trusting nature leaves them open to people not deserving of their trust. Trust needs to be seen as a biologically shaped manner in which one lives life, not as an environmentally driven response to perceptions of people's trustworthiness (see Fehr et al. 2005).

Previous research, much of it in experimental economics, has turned to a similar experimental design but has been motivated by different research questions. Often these researchers have been interested in comparing decisions by decision makers who earned the right to be a decision maker (usually by winning a trivia contest) with decisions by decision makers who did not earn that position. They find that decision makers who believe they earned their position tend to be less generous to others (see Hoffman and Spitzer 1985; Hoffman et al. 2000), ${ }^{10}$ but our interest is in the reaction of people to decisions and not in the nature of the decision itself and here the literature is much less developed. The lone study that is relevant reports mixed results in which reactions to decision makers who earned their position seem to vary depending upon the level of stakes involved (Hoffman, McCabe, and Smith 2000). All in all, the empirical evidence on the extent to which people are more or less accepting of decisions depending upon the manner by which decision makers acquired their position is sparse and inconclusive-and never considers the possibility that only a certain type of person will care about such nonoutcome matters.

\footnotetext{
${ }^{10}$ See Hoffman and Spitzer (1985) for a discussion of the theoretical reasons why decision maker entitlement (or desert) should affect behavior.
} 
Thus, we were motivated to conduct our own experimental research on the topic. We recruited subjects from a broad cross section of the population of a mid-sized U.S. city. ${ }^{11}$ Each experimental subject was led to believe that another person (in actuality, an experimental fiction) had the authority to divide a small pot of money (\$20) between him/herself and the subject. We next informed the subject that the allocator had decided to keep $\$ 17$ and to pass along just $\$ 3$ to the subject and then we ascertained the reaction of the subject to this monetarily meaningful decision. ${ }^{12}$ By not using a real allocator, we were able to standardize the outcome. All that we varied in this first part of the experiment was the manner by which the subject believed the allocator came to hold the position of allocator (or decision maker).

There are two possibilities. Subjects in the first cell were told the individual with whom they had been paired was made the allocator because he or she wanted that position more than the subject. Subjects in the second cell were told that the individual with whom they had been paired was made the allocator because he or she had earned that position. The manner in which we made these presentations believable follows. Subjects were first told that they had been randomly matched with an anonymous second subject who was contemporaneously at a computer terminal in another room and with whom they would play only one game. In a pretest questionnaire, subjects were asked to rank how much they wanted to be the allocator on a scale of 1 to 10 with 10 being an extreme desire to make the allocation decision. We also asked them how much total time in minutes they would spend traveling to and from the experimental site. Those subjects randomly assigned to Cell 1 were told that the player with whom they had been matched gave a higher number than was given by the subject on the "want to be decision maker" spectrum. ${ }^{13}$ Those

\footnotetext{
${ }^{11}$ Subjects were recruited using newspaper ads, posters and community listserves, which produced a very diverse pool of respondents. The average age was 37 , with a median income of $\$ 20,000$ to $\$ 40,000$. There were slightly more males $(55 \%$ of our $\mathrm{N})$ than females (45\%), and most were white (approximately $70 \%$ ). We make no claims that this constitutes a random sample, but do suggest that we have a much more representative pool of subjects than the undergraduate population that is typical of experimental research.

${ }^{12}$ Following the experiment, all subjects were thoroughly debriefed and given the full pot, i.e. after the experiment was completed all subjects received $\$ 20$ for their participation.

${ }^{13}$ In the very few cases in which the subject answered 10 (the highest score possible), the subject was informed that the other player also answered 10 and had been randomly selected to be the allocator.
}

subjects randomly assigned to Cell 2 were told that the individual with whom they had been matched had invested more travel time in coming to the experiment. $^{14}$

As mentioned above, after these preliminaries, each subject was then informed of the allocator's decision to pass along only $\$ 3$ of the $\$ 20$ and asked, via several items in a posttest questionnaire, to provide reactions. The most relevant of these items for our purposes pertained to satisfaction with the outcome (the \$3) and perception of the fairness of the allocator. More specifically, subjects were asked how fair or unfair they thought the allocator was, using a 7-point scale with 6 equating to "very unfair" and 0 to "very fair," and they were asked to estimate their satisfaction with the money they received, again on a 7-point scale with 6 equating to "very unsatisfied" and 0 to "very satisfied." As it turns out, level of satisfaction and perception of fairness were highly correlated $(r=.75)$ so we combined these two measures into a simple additive "scale of negativity" ranging from 0 to 12 with higher values being greater negativity.

An additional and final dependent variable we employed measures the tendency to accept the decision made by the allocator. We gave subjects in each of the cells the opportunity to accept or reject the offer proposed, with the stipulation that if they rejected the proposal neither the subject nor the allocator would receive anything. This arrangement is commonly known as the ultimatum game (for good reviews, see Guth and Tietz 1990; Nowak, Page, and Sigmund 2000; Thaler 1992). The ultimatum game is now the most widely employed experimental scenario in the social sciences, and the results from it are consistent. Allocators are reasonably generous in their offers and receivers are surprisingly willing to reject allocations that are ungenerous. Our theory, as might be expected, is that subjects faced with an allocator who craved power will be much more likely to reject the $\$ 3$ proposal (even though rejecting it costs them \$3) than will subjects dealing with an allocator who earned the position by traveling a relatively long time to and from the experimental site.

By comparing the fairness, satisfaction, and acceptance responses of subjects across the two cells, we can test the expectation that people are most averse to decisions made by those who want to be decision makers and most accepting of decisions made by those

\footnotetext{
${ }^{14}$ No subjects reported the highest possible driving time, so we could always say that the other player spent more time traveling.
} 
who unwittingly earned the right to be decision maker (that is, those who are deserving but not ambitious). Expectations based on a more rational or outcomebased view of human behavior would not anticipate reaction to a $\$ 3$ allocation in a single-play game to vary depending upon whether that allocation was rendered by a decision maker who is either ambitious or deserving. After all, if outcome is all that matters, $\$ 3$ is $\$ 3$.

But our core expectation is that only a certain type of person is sensitive to the characteristics of the decision maker. The well-known NES item on the degree to which the subject trusts other people was included in the pre-test. Those people who are more trusting of others should be more sensitive to ambition and avarice in decision makers. Thus, trusting subjects should respond favorably to unselfish decision makers who earned their position and unfavorably to selfish decision makers who achieved their position only as a result of ambition. Untrusting subjects should display little difference in response regardless of the decision maker.

\section{Findings}

Figure 1 presents our results on the varying reactions of subjects to decisions depending upon the reason the decision maker obtained that authoritative position. Remember that some subjects believed they were dealing with a decision maker who received the position out of raw ambition while others believed they were dealing with a decision maker who received the position because they earned it. Our two primary measures of subject reaction were described earlier. The first is a scale of negativity that runs from 0 to 12 with 12 being a very negative reaction (as expressed in posttest items asking about the subject's satisfaction with the decision and perceptions of the fairness of the decision maker), 0 being the most positive reaction possible, and 6 being a neutral reaction. This scale is marked on the right axis of the figures. The second measure of reaction is whether the subject decided to accept the $\$ 3$ allocation received or to reject it, leaving both subject and allocator with no money (except the participation fee). We show the percent who reject and key these bars to the left axes.

On the whole, reactions are more negative than positive as is to be expected when the decision itself is highly unfavorable to the subject and highly favorable to the allocator so we show only the neutral to fully negative halves of the ranges. But our interest is in the variation in this reaction that might result from the manner in which allocators came to power and here we see a mild effect. Subjects report more negative reactions when decision makers wanted power (9.37 on the scale of negativity) than when decision makers earned power (7.93). Similarly, more subjects decided to reject the $\$ 3$ allocation when it was made by an ambitious decision maker (47\%) than when it was made by a deserving decision maker (30\%). Though these relationships run in the anticipated direction, neither achieves statistical significance at traditionally accepted levels when all subjects are included.

\section{Figure 1 Effects of Reason for Becoming Decision Maker on Reactions to Unfavorable Decisions}

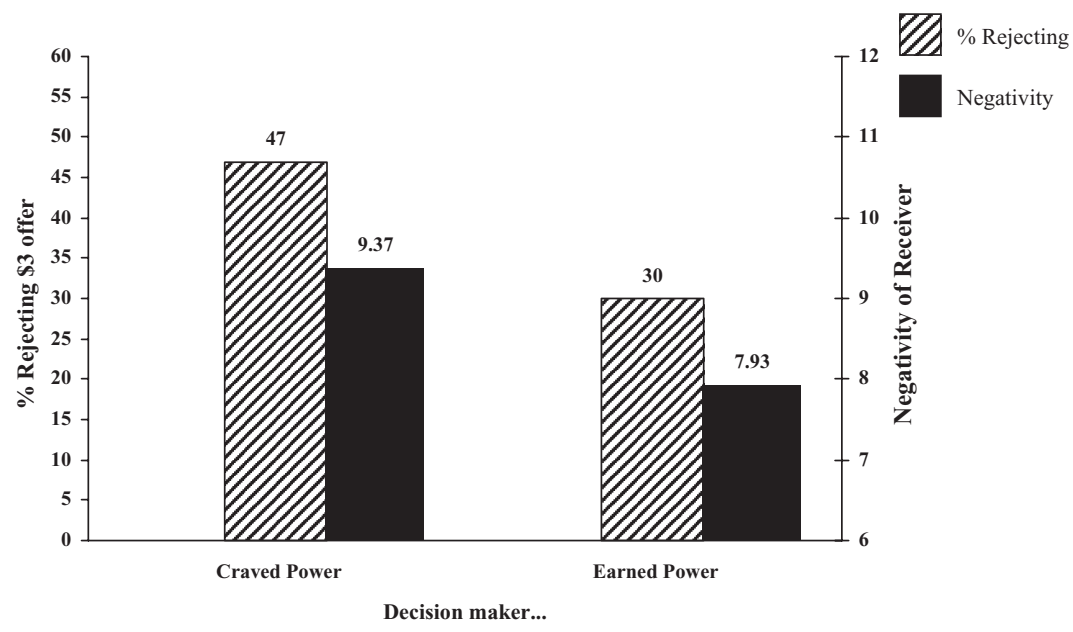

$\chi 2=1.76, p=.184(\%$ Rejecting $\$ 3$ Offer $)$

$\mathrm{t}=1.69, p<.10$ (Negativity of Receiver)

$\mathrm{N}=60$ 


\section{FIgURE 2 Effects of Trusting and Distrustful Dispositions on Reactions to Unfavorable Decisions}

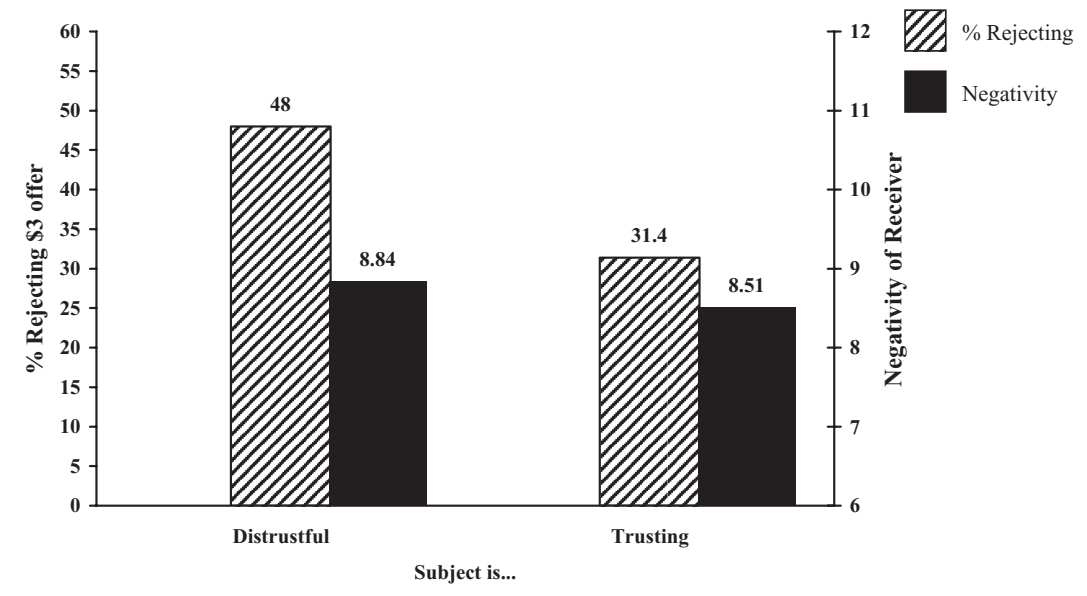

$\chi 2=1.69, p=.193$ (\% Rejecting of $\$ 3$ Offer) $\mathrm{t}=-.372, p<.712$ (Negativity of Receiver) $\mathrm{N}=60$

Figure 2 reports that, regardless of the reason the decision maker received authority, people who profess to be generally trusting of other people are not as negatively disposed as those who claim "you can't be too careful with people." Though neither relationship achieves statistical significance, trusting people score lower than less trusting people on the scale of negativity ( 8.51 to 8.84 ) and are less likely to reject the $\$ 3$ allocation (31.4\% to $48 \%)$. Subjects who believe you can't be too careful with other people may be a little crankier than trusting people but the direct effects of disposition are minimal.

Our real interest, however, is in the interaction of the method by which the decision maker acquired power and the type of person the subject happens to be. Remember that our core prediction is that trusting people will be very sensitive to all kinds of factors relevant to the decision maker, including how that person became the decision maker. Thus, while untrusting subjects should display only minimal differences in reaction depending upon whether the allocator craved power or earned power, this distinction should matter greatly for trusting subjects. The test of this hypothesis is reported in the two panels of Figure 3, and the results could hardly be more supportive of our central prediction.

For those subjects who believe you can't be too careful with people (and whom we label "distrustful" in the top panel of Figure 3) the method of power acquisition means little. Whether the decision maker craved power or earned power does not affect the behavior of distrustful people. Scores on the negativity scale are actually slightly lower for ambitious decision makers (8.50) than for deserving decision makers (9.27), and the tendency to reject the unfavorable allocation is slightly higher when the decision maker is meritorious (54\%) than when the decision maker is ambitious (43\%). These differences are all substantively and statistically insignificant. Shifting to those subjects who report that they are generally trusting, the story changes completely. Whereas the less trusting were equally negative for decision makers who craved power and for decision makers who earned power, the more trusting (the bottom panel of Figure 3) are extremely sensitive to the method of position acquisition. Among trusting subjects, ambitious allocators are viewed very negatively ( 10.13 on a scale of 0 to 12$)$ and are unlikely to have unfavorable decisions accepted ( $50 \%$ are rejected) but meritorious allocators are the recipients of much less negativity (just 7.16 on the same scale) and are much less likely to have their decision rejected. In fact, only $16 \%$ of trusting subjects rejected the miserly $\$ 3$ allocation when it was made by an allocator who earned that position. These differences easily attain statistical significance $(p<.05)$ even with the small Ns characteristic of experimental research. ${ }^{15}$ Trusting people are affected by the manner in which office holders come to be office holders while less trusting people are largely unaffected.

\footnotetext{
${ }^{15}$ Two-tailed tests are employed throughout even though our theory provides us with clear directional hypotheses. Maximizing the $\mathrm{N}$ using an ANOVA analysis repeats the basic story relayed in Figures 1-3. There are no main effects for trust or the means of gaining power on negativity ratings, but a strongly significant interaction effect $(\mathrm{F}=4.93, p<.05)$.
} 
Figure 3 Effects of Reason for Becoming Decision Maker on Reactions to Unfavorable Decisions, Trusting and Distrustful Subjects Analyzed Separately

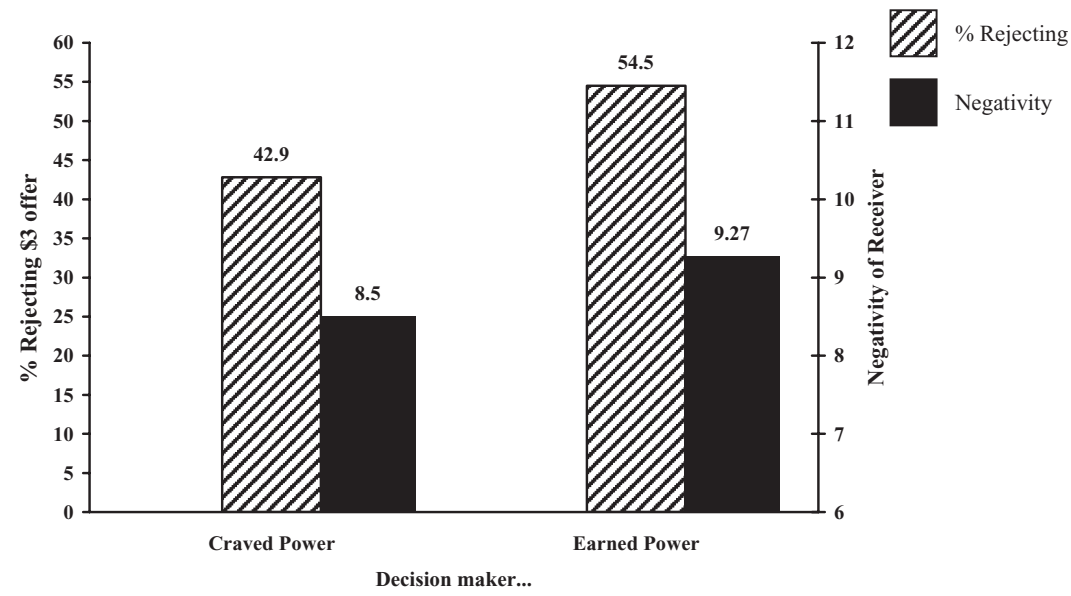

Distrustful $(\mathrm{N}=25)$

$\chi^{2}=.337, p=.561(\%$ Rejecting of $\$ 3$ Offer $)$

$\mathrm{t}=.546, p<.590$ (Negativity of Receiver)

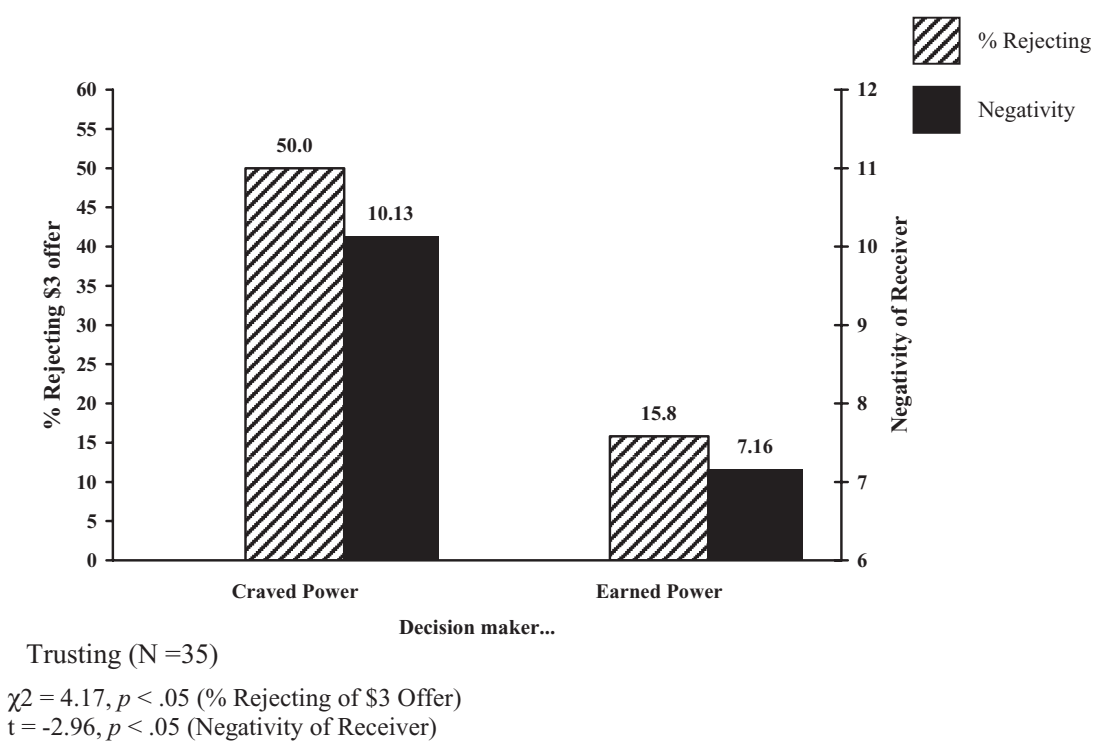

Our analysis of the motivations of decision makers after they came to power parallels the foregoing evidence on the reasons they were given power in the first place. After the subjects had recorded their responses to the unfair allocation (i.e., the data used in the preceding analysis), they were told that the allocator was actually a third-party divider who had no financial interest in the decision. This created the impression that though the subject still got only $\$ 3$ the allocator did not get to keep $\$ 17$, but had decided for whatever reason to give that $\$ 17$ to some other unknown individual. ${ }^{16}$ Thus, the outcome is the same for the subject but the motivation of the allocator is

${ }^{16}$ The experimental protocol called for an initial unfair decision ( $\$ 17$ for the allocator, $\$ 3$ for the subject), and for the subjects to record their responses to that decision. After those responses were complete, subjects were told that the allocator was actually a thirdparty divider and did not get to keep the $\$ 17$. They were then asked to complete the same two questions used to create the negativity scale. If the outcome, rather than the self-interested position of the decision maker, is driving reactions there should be no difference in these responses; the outcome did not change, only the impression of the motivations of the allocator. 


\section{Figure 4 Effects of Decison Maker Self-Interest on Reactions to Unfavorable Decisions}

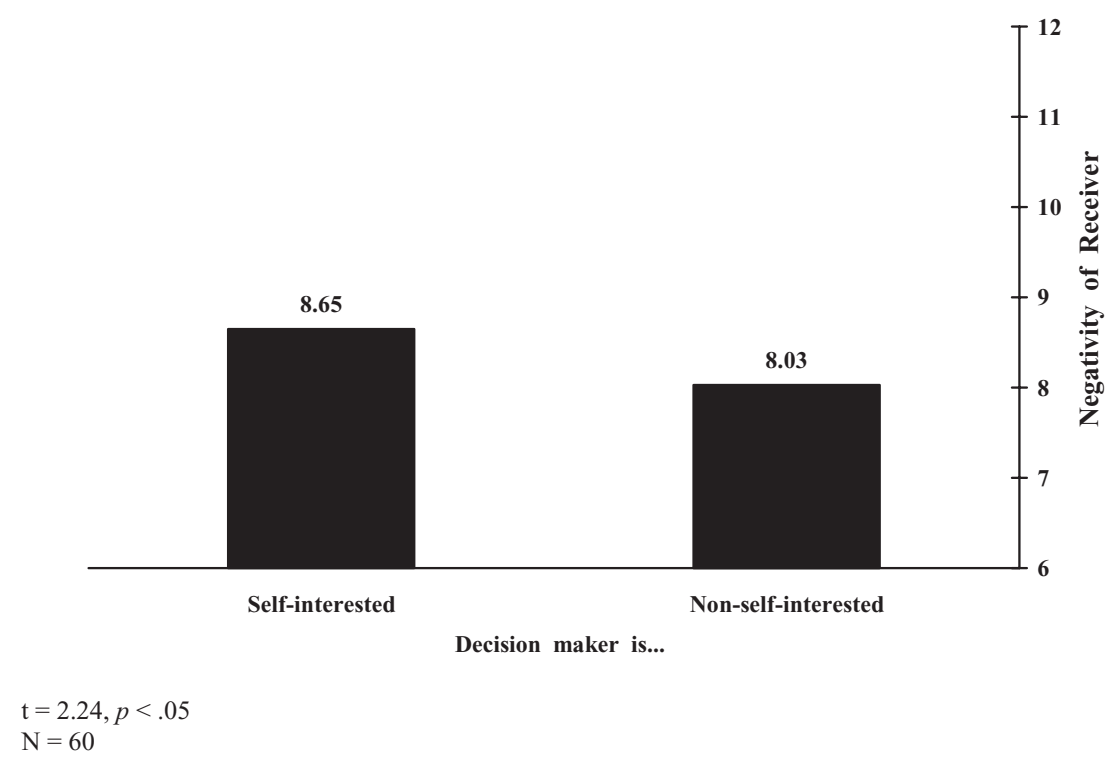

different in that the decision was not self-interested. Parallel to our expectations for the manner of becoming allocator, we believe subjects' reactions to selfinterested decision makers will be more negative than their reactions to nonself-interested decision makers but that this increased negativity due to allocator selfinterest will be primarily evident among those subjects who are trusting. As before, we predict that less trusting subjects will be largely unaffected by variations in the level of self-interest of the decision maker.

The results are again supportive of our expectations. In this portion of the study, subjects were not asked to make a decision on whether or not to accept the proposed allocation but they were asked the two items needed to construct the scale of negativity. Figure 4 shows that, with the decision itself held constant, nonself-interested decision makers are the targets of less negativity than are self-interested decision makers. Though the difference is substantively quite small (8.65 to 8.03), it does achieve statistical significance at the .05 level. The direct effects of a trusting or a distrustful disposition were already presented in Figure 2 where we found mild and statistically insignificant primary effects (distrustful subjects scored 8.84 on the scale of negativity with trusting subjects scoring 8.51). But our main interest is in the interaction of subject disposition and decision-maker motive, and these results are contained in Figure 5.

Here we see once more that the relationship between decision-maker traits and the negativity resulting from an unfavorable decision is stronger among trusting subjects. For less trusting subjects, the relationship between decision-maker self-interest and the negativity of subject reaction is small (8.84 to 8.24) and statistically insignificant (see the top panel of Figure 5) but the relationship is slightly larger and statistically significant for trusting subjects (the bottom panel of Figure 5). The level of significance drops to the more permissive .10 level but this is not surprising as we continue to carve up an already small $\mathrm{N}$ and since we employ the more demanding twotailed tests. The conclusion seems to be that people are sensitive to nonoutcome factors surrounding decisions, especially the traits of decision makers, but that, as expected, this sensitivity is largely confined to individuals whose trusting attitude toward others makes it necessary for them to be sensitive to whether or not decision makers appear to be ambitious and/or selfinterested.

\section{Conclusion}

Why do people care about things that are irrelevant to outcome? For the same reason they care about the outcomes received by others even if the outcome they receive is held constant (on the importance of relative as opposed to absolute gain, see Frank 1999; Kahn and Murnighan 1993): People care about the health of their group and their own place in it. Group viability and individual place are indicated to some extent by the absolute value of resource distribution decisions 
Figure 5 Effects of Decison Maker Self-Interest on Reactions to Unfavorable Decisions, Trusting and Distrustful Subjects Analyzed Separately

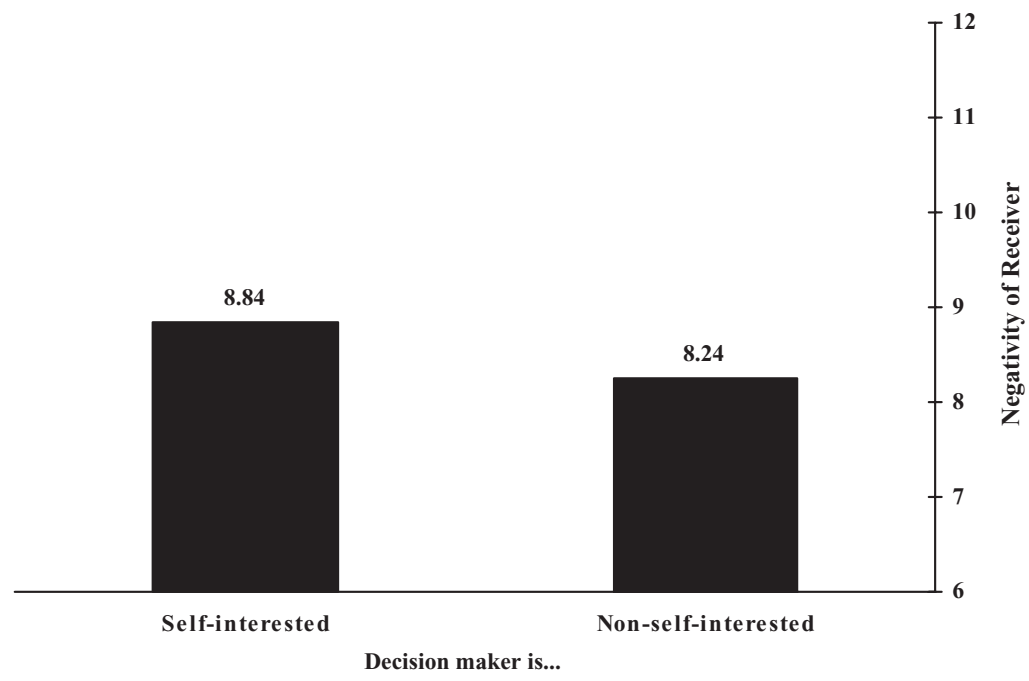

Distrustful $(\mathrm{N}=25)$

$\mathrm{t}=1.4, p=.174$

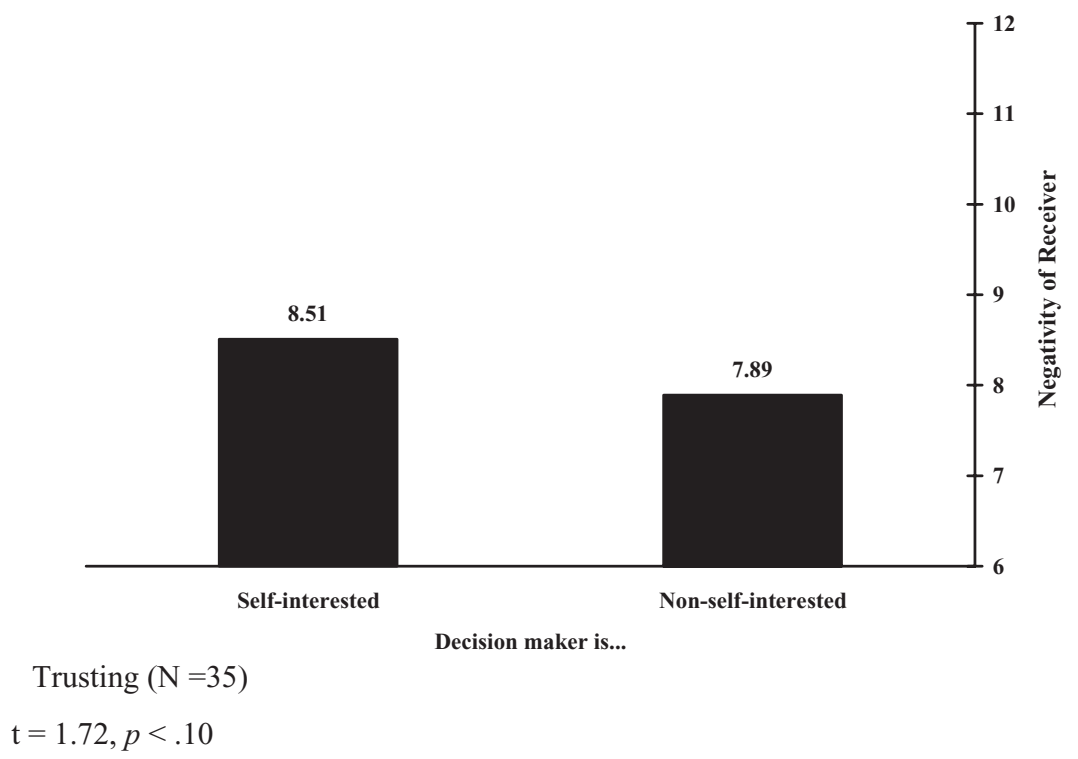

but they are better indicated by the relative value and by a variety of nonoutcome factors (on the interaction between outcome and process, see Brockner and Wiesenfeld 1996). Evolutionary pressures may have led to the predisposition of some human beings to be sensitive to nonoutcome factors because groups in which no one cares about group health are likely to find themselves at a disadvantage. In this sense, evolutionary theory helps to explain findings in the procedural justice literature as well as our findings on people's aversion to decision makers who desire power or who use power to benefit themselves at others' expense. It also helps to explain the existence of different types of people within a group (in this case, differences in sensitivity to leader traits).

The implication of our findings is that those who wish to improve citizens' perceptions of governmental decisions and of decision makers, as well as increase the willingness of citizens to accept those decisions, should take steps to make it so that people believe elected officials are not in office because of a desire for authority but rather because they have earned or otherwise acquired authority without making any conscious effort to do so. Eighty-four percent of trusting 
people accepted an allocation of just $\$ 3$ out of $\$ 20$ when it was proposed by a decision maker who earned, not sought, that position, and that is a notably high acceptance rate for such an unfavorable decision. Also, reformers should take steps to make it so that people believe decision makers are not able to better themselves, to feather their own nests, by virtue of the decisions they make. A decision made by an official believed to be nonself-interested, deserving, and devoid of ambition will be more satisfying than an identical decision made by a self-interested decision maker. A final implication is that the changes just described should not be expected to affect all citizens since some are largely unconcerned with leadership traits and other nonoutcome variables.

A cynical interpretation of these findings is that merely by manipulating citizens' perceptions of political decision makers, some of them can be led to accept and to tolerate virtually any decision/outcome. Though we believe it is important to demonstrate the degree to which people's perception of a decisionmaker's motive and ambition for authority affects their reactions, we also are convinced that people are difficult to fool. They are quite adept at identifying individuals, especially decision makers, who are selfinterested and ambitious. Experimental work provides evidence of people's skills in these areas (Frank 1988). Though some people may be able to cover their ambition and self-interest, most selfish, machinating people are identifiable. Accordingly, the best way to make people believe decision makers are meritorious, unambitious, and nonself-interested is to obtain decision makers who are meritorious, unambitious, and nonself-interested.

Perhaps by underscoring the sensitivity of a subset of the population to the perceived motives, intentions, and ambitions of decision makers, we can encourage scholars and political reformers, to the extent they wish to improve the public's view of government, to design reforms that are targeted at the deeper sources of public dissatisfaction: people's distaste for officeholders they perceive to be something other than reticent, deserving, altruistic leaders. Even if governmental outcomes continue to disappoint people, the results presented here suggest that altering the mechanisms by which officials are chosen and then making it difficult or impossible for these officials to act in a self-interested fashion would improve the standing of government in representative democracies. People do not necessarily need to receive more resources to be happy, but they do need decisions to be made by decision makers who are not selfishly motivated and who are not driven by ambition. Reactions to authoritative decisions are much richer than preprogrammed responses to the specific outcome of the decision in question.

\section{Acknowledgments}

An earlier version of this paper was presented at the 2004 annual meeting of the Midwest Political Science Association. The authors gratefully acknowledge the assistance of Jonathan Jones, Eric Whitaker, and Daniel B. Braaten, and especially the computer programming and guidance of Brennen Bearnes. Financial support was provided by the University of Nebraska Foundation Fund \#1915.

\section{Manuscript submitted 22 December 2005 \\ Manuscript accepted for publication 30 July 2006}

\section{References}

Alford, John R., Carolyn L. Funk, and John R. Hibbing. 2005. “Are Political Orientations Genetically Transmitted?" American Political Science Review 99 (2): 153-68.

Anderson, Christopher J., and Christine A. Guillory. 1997. "Political Institutions and Satisfaction with Democracy." American Political Science Review 91 (1): 66-81.

Baron-Cohen, Simon. 2003. The Essential Difference. New York: Perseus.

Boehm, Christopher. 1999. Hierarchy in the Forest: The Evolution of Egalitarian Behavior. Cambridge: Harvard University Press.

Bouchard, Thomas J., Jr., and Matt McGue. 2003. "Genetic and Environmental Influences on Human Psychological Differences." Iournal of Neurobiology 54 (1): 4-45.

Bowles, Samuel. 2004. Microeconomics: Behavior, Institutions, and Evolution. Princeton: Princeton University Press.

Brockner, Joel, and Batia M. Wiesenfeld. 1996. "An Integrative Framework for Explaining Reactions to Decisions: Interactive Effects of Outcomes and Procedures." Psychological Bulletin 120 (2): 189-208.

Byrne, Richard W., and Andrew Whiten. 1988. Machiavellian Intelligence: Social Expertise and the Evolution of Intellect in Monkeys, Apes, and Humans. New York: Oxford University Press.

Carmen, Ira H. 2004. Politics in the Laboratory. Madison: University of Wisconsin Press.

Carmen, Ira H. 2006. "Genetic Configurations of Political Phenomena: New Theories, New Methods." Presented at the annual meeting of the Midwest Political Science Association.

Cason, Timothy N., Tatsuyoshi Saijo, Takehiko Yamato, and Konomu Yokotani. 2003. "Non-excludable Public Goods Experiments." Games and Economic Behavior 49 (1): 81-102.

Caspi, Avshalom, Joseph McClay, Terrie E. Moffitt, Jonathan Mill, Judy Martin, Ian W. Craig, Alan Taylor, and Richie Poulton. 2003. "Influence of Life Stress on Depression: Moderation by a Polymorphism in the 5-HTT Gene." Science 301 (5631): 386-89. 
Chiappe, Dan, Adam Brown, and Marisela Rodriquez. 2002. "Remembering the Faces of Potential Cheaters and Cooperators in Social Contract Situations." Presented at the annual meeting of the Human Behavior and Evolution Society, New Brunswick, NJ.

Citrin, Jack. 1974. "Comment: The Political Relevance of Trust in Government.” American Political Science Review 68 (3): 973-88.

Cosmides, Leda. 1989. "The Logic of Social Exchange: Has Natural Selection Shaped How Humans Reason?” Cognition 31 (3): 187-276.

Cosmides, Leda, and John Tooby. 1992. "Cognitive Adaptations for Social Exchange." In The Adapted Mind, eds. Jerome H. Barkow, Leda Cosmides, and John Tooby. Oxford: Oxford University Press, pp. 163-228.

Craig, Stephen C. 1993. The Malevolent Leaders. Boulder, CO: Westview Press.

Della Porta, Donatella. 2000. "Social Capital, Beliefs in Government, and Political Corruption." In Disaffected Democracies, eds. Susan J. Pharr and Robert D. Putnam. Princeton: Princeton University Press, pp. 202-28.

Delli Carpini, Michael X., and Scott Keeter. 1996. What Americans Know about Politics and Why It Matters. New Haven: Yale University Press.

De Waal, Frans. 1996. Good Natured: The Origins of Right and Wrong in Humans and other Animals. Cambridge: Harvard University Press.

Diamond, Jared. 1997. Guns, Germs, and Steel. New York: W.W. Norton.

Durr, Robert H., John B. Gilmour, and Christina Wolbrecht. 1997. "Explaining Congressional Approval." American Iournal of Political Science 41 (1): 175-207.

Easton, David. 1965. A Framework for Political Analysis. Englewood Cliffs, NJ: Prentice-Hall.

Ely, John Hart. 1980. Democracy and Distrust. Cambridge: Cambridge University Press.

Falk, Armin, Ernst Fehr, and Urs Fischbacher. 2003. "On the Nature of Fair Behavior." Economic Inquiry 41 (1): 20-26.

Fehr, Ernst, and Simon Gachter. 2002. "Altruistic Punishment in Humans.” Nature 415 (10 January): 137-40.

Fehr, Ernst, Michael Kosfeld, Markus Heinrics, Paul Zak, and Urs Fischbacher. 2005. "Oxytocin and Trust in Humans." Nature 435 (2 June): $673-76$.

Fowler, James H., Laura A. Baker, and Jeremy C. Pope. 2006. "The Genetic Basis of Political Cooperation." Paper presented at the Hendricks Symposium, Lincoln, Nebraska, October 13-14.

Frank, Robert H. 1988. Passions within Reason. New York: W.W. Norton.

Frank, Robert H. 1999. Luxury Fever. New York: Free Press.

Frank, Robert H., Thomas Gilovich, and Dennis T. Regan. 1993. "Does Studying Economics Inhibit Cooperation?" Lournal of Economic Perspectives 7 (2): 159-71.

Gosling, Samuel D., and Oliver P. John. 1999. "Personality Dimensions in Nonhuman Animals: A Cross-Species Review." Current Directions in Psychological Science 8 (3): 69-75.

Guth, Werner, and Reihard Tietz. 1990. "Ultimatum Bargaining Behavior: A Survey and Comparison of Experimental Results." Iournal of Economic Psychology 11 (3): 417-49.

Hammond, Ross. 2000. "Endogenous Transition Dynamics in Corruption: An Agent-based Computer Model." Typescript. Washington, DC: Brookings Institution.

Harpending, Henry, and Gregory Cochran. 2002. "In Our Genes." Proceedings of the National Academy of Sciences 99 (1): 10-12.
Hetherington, Marc J. 2005. Why Trust Matters: Declining Political Trust and the Demise of American Liberalism. Princeton: Princeton University Press.

Hibbing, John R., and John R. Alford. 2004. "Accepting Authoritative Decisions: Humans as Wary Cooperators." American Lournal of Political Science 48 (1): 62-76.

Hibbing, John R., and Elizabeth Theiss-Morse. 2002. Stealth Democracy: Americans' Beliefs about How Government Should Work. Cambridge: Cambridge University Press.

Hoffman, Elizabeth, and Matthew L. Spitzer. 1985. "Entitlements, Rights and Fairness: An Experimental Examination of Subjects' Concepts of Distributive Justice." Iournal of Legal Studies 14 (2): 259-97.

Hoffman, Elizabeth, Kevin McCabe, Keith Shachat, and Vernon L. Smith. 2000. "Preferences, Property Rights, and Anonymity in Bargaining Games." In Bargaining and Market Behavior, ed. Vernon L. Smith. Cambridge: Cambridge University Press, pp. 79-89.

Hoffman, Elizabeth, Kevin McCabe, and Vernon L. Smith. 2000. "On Expectations and the Monetary Stakes in Ultimatum Games." In Bargaining and Market Behavior, ed. Vernon L. Smith. Cambridge: Cambridge University Press, pp. 139-51.

Kahn, Lawrence M., and Keith Murnighan. 1993. “General Experimentation Bargaining in Demand Games with Outside Options." American Economic Review 83: 1260-80.

Komorita, Samuel S., and Craig D. Parks. 1995. "Intergroup Relations: Mixed-Motive Interaction." Annual Review of Psychology 46 (January): 183-207.

Kurzban, Robert, and Daniel Houser. 2005. "Experiments Investigating Cooperative Types in Humans: A Complement to Evolutionary Theory and Simulations." Proceedings of the National Academv of Sciences 102 (5): 1803-07.

Lawrence, Robert Z. 1997. "Is It Really the Economy, Stupid?" In Why People Don't Trust Government, eds. Joseph S. Nye, Jr., Philip D. Zelikow, and David C. King. Cambridge: Harvard University Press, pp. 111-32.

Lee, Richard B., and Irven Devore. 1968. "Problems in the Study of Hunters and Gatherers." In Man the Hunter, eds. Richard B. Lee and Irven Devore. Chicago: Aldrine, pp. 3-12.

Lind, E. Allan, and Tom R. Tyler. 1988. The Social Psychology of Procedural Justice. New York: Plenum Press.

Lipset, Seymour Martin, and William Schneider. 1987. The Confidence Gap. Baltimore: The Johns Hopkins University Press.

Mansbridge, Jane J. 1980. Beyond Adversary Democracy. Chicago: University of Chicago Press.

Marcus, George E. 2002. The Sentimental Citizen: Emotion in Democratic Politics. State College: Pennsylvania State University Press.

Marcus, George E., W. Russell Neuman, and Michael MacKuen. 2000. Affective Intelligence and Political Judgment. Chicago: University of Chicago Press.

Martin, N. G., L. J. Eaves, A. C. Heath, R. Jardine, L. M. Feingold, and H. J. Eysenck. 1986. "Transmission of Social Attitudes." Proceedings of the National Academv of Sciences 83 (12): 4364 68.

Masters, Roger D. 1982. “Nice Guys Don't Finish Last.” Presented at the Meeting of the American Association for the Advancement of Science, Washington.

McAndrew, Francis T. 2002. "New Evolutionary Perspectives on Altruism: Multilevel-Selection and Costly-Signaling Theories." Current Directions in Psychological Science 11 (2): 171-93.

McDermott, Rose. 2004. "The Feeling of Rationality: The Meaning of Neuroscientific Advances for Political Science." Perspectives on Politics 2 (4): 691-706. 
Milgram, Stanley. 1974. Obedience to Authority: An Experimental View. New York: Harper Colophon.

Miller, Arthur H. 1974. "Political Issues and Trust in Government, 1964-70.” American Political Science Review 68 (3): 951-72.

Monroe, Kristen Renwick. 2001. "Paradigm Shift: From Rational Choice to Perspective." International Political Science Review 22 (2): 151-72.

Nowak, Martin A., Karen M. Page, and Karl Sigmund. 2000. "Fairness versus Reason in the Ultimatum Game." Science 289 (5485): 1773-75.

Nye, Joseph S., Jr., Philip D. Zelikow, and David C. King, eds. 1997. Why People Don't Trust Government. Cambridge: Harvard University Press.

Orbell, John M., and Robyn M. Dawes. 1991. "A Cognitive Miser Theory of Cooperators' Advantage.” American Political Science Review 85 (2): 515-28.

Orbell, John, Tomonori Morikawa, Jason Hartwig, James Hanley, and Nicholas Allen. 2004. "Machiavellian Intelligence as a Basis for the Evolution of Cooperative Dispositions." American Political Science Review 98 (1): 1-16.

Orren, Gary. 1997. "Fall from Grace: The Public's Loss of Faith in Government." In Why People Don't Trust Government, ed. Joseph S. Nye, Jr., Philip D. Zelikow, and David C. King. Cambridge: Harvard University Press, pp. 77-107.

Ostrom, Elinor. 1998. "A Behavioral Approach to the Rational Choice Theory of Collective Action." American Political Science Review 92 (1): 1-22.

Peterson, Michael Bang. 2006. "Evolutionary Psychology, Political Science, and Public Opinion.” Typescript. University of Aarhus.

Pharr, Susan J. 2000. "Officials' Misconduct and Public Distrust." In Disaffected Democracies, eds. Susan J. Pharr and Robert D. Putnam. Princeton: Princeton University Press, pp. 173-201.

Pharr, Susan J., and Robert D. Putnam, eds. 2000. Disaffected Democracies. Princeton: Princeton University Press.

Popkin, Samuel L. 1991. The Reasoning Voter. Chicago: University of Chicago Press.

Price, Michael E., Leda Cosmides, and John Tooby. 2002. "Punitive Sentiment as an Anti-Free Rider Psychological Device." Evolution and Human Behavior 23 (3): 203-31.

Rauch, Jonathan. 2002. "Seeing Around Corners." Atlantic Monthly 289 (4): 35-48.

Rushton, J. Philipe, Christine H. Littlefield, and Charles J. Lumsden. 1986. "Gene-Culture Coevolution of Complex Social Behavior: Human Altruism and Mate Choice." Proceedings of the National Academy of Sciences 83 (19): 7340-43.

Scharlemannk, Jorn P., Catherine C. Eckel, Alex Karcelnik, and Rick Wilson. 2001. "The Value of a Smile." Iournal of Economic Psychology 22 (5): 617-40.

Sell, Jane, Michael J. Lovaglia, Elizabeth A. Mannix, Charles D. Samuelson, and Rick Wilson. 2004. "Investigating Conflict, Power, and Status within and among Groups." Small Group Research 35 (1): 44-72.

Sherif, Muzafer. 1937. "An Experimental Approach to the Study of Attitudes." Sociometry 1 (1/2): 90-98.

Simon, Herbert A. 1990. "A Mechanism for Social Selection and Successful Altruism.” Science 250 (4988): 1665-8.
Smirnov, Oleg, Holly Arrow, Doug Kennett, and John Orbell. 2006. "Why Are People Willing to Die for their Country? The Evolution of 'Heroism' as Domain Specific Altruism." Typescript. University of Oregon.

Sober, Elliott, and David Sloan Wilson. 1998. Unto Others: The Evolution and Psychology of Unselfish Behavior. Cambridge: Harvard University Press.

Somit, Albert, and Steven A. Peterson. 1997. Darwinism, Dominance, and Democracy. Westport, CT: Praeger.

Sullivan, Denis G., and Roger D. Masters. 1988. "Happy Warriors: Leaders' Facial Displays, Viewers' Emotions, and Political Support." American Journal of Political Science 32 (2): 345-68.

Thaler, Richard H. 1992. "The Ultimatum Game." In The Winner's Curse, ed. Richard H. Thaler. Princeton: Princeton University Press, pp. 21-35.

Thibaut, John W., and Laurens Walker. 1975. Procedural Justice: A Psychological Analysis. Hillsdale, NJ: Erlbaum.

Tooby, John, and Leda Cosmides. 1992. "The Psychological Foundations of Culture." In The Adapted Mind, eds. Jerome H. Barkow, Leda Cosmides, and John Tooby. Oxford: Oxford University Press, pp. 19-136.

Tyler, Tom R. 1990. Why People Obey the Law. New Haven: Yale University Press.

Tyler, Tom R. 1994. "Psychological Models of the Justice Motive: Antecedents of Distributive and Procedural Justice." Iournal of Personality and Social Psychology 67 (5): 850-63.

Tyler, Tom R. 2001. "The Psychology of Public Dissatisfaction with Government." In What Is it about Government that Americans Dislike? eds. John R. Hibbing and Elizabeth Theiss-Morse. Cambridge: Cambridge University Press, pp. 227-42.

Tyler, Tom R., Jonathan D. Casper, and Bonny Fischer. 1989. "Maintaining Allegiance toward Political Authorities: The Role of Prior Attitudes and the Use of Fair Procedures." American Lournal of Political Science 33 (3): 629-52.

Tyler, Tom R., Kenneth A. Rasinski, and N. Spodick. 1985. "The Influence of Voice on Satisfaction with Leaders: Exploring the Meaning of Process Control." Lournal of Personality and Social Psychology 48 (1): 72-91.

Wilson, James Q. 1993. The Moral Sense. New York: Free Press.

Wilson, Rick, Catherine C. Eckel, and Martin Johnson. 2002. "Fairness and Rejection in the Ultimatum Bargaining Game." Political Analysis 10 (4): 376-93.

Kevin B. Smith is professor of political science, University of Nebraska-Lincoln, Lincoln, NE 685880328. Christopher W. Larimer is assistant professor of political science, University of Northern Iowa, Cedar Falls, IA 50614-0404. Levente Littvay is visiting assistant professor, Central European University, Budapest, Goldmark K. u. 14, Hungary. John R. Hibbing is Foundation Regents University professor of political science, University of Nebraska-Lincoln, Lincoln, NE 68588-0328. 